\title{
A Conserved Idiotype and Antibodies to Retroviral Proteins in Systemic Lupus Erythematosus
}

\author{
Norman Talal," Robert F. Garry," Peter H. Schur," Steve Alexander," Michael J. Dauphinée," Iraklis H. Livas," \\ Ana Ballester," Masami Takei," and Howard Dang* \\ *Clinical Immunology Section, Audie L. Murphy Memorial Veterans Hospital and the Department of Medicine, The University of \\ Texas Health Science Center, San Antonio, Texas 78284; ${ }^{\ddagger}$ Department of Microbiology and Immunology, Tulane University School of \\ Medicine, New Orleans, Louisiana 70112; \$Biotech Research Laboratories, Rockville, Maryland 20850; and "Brigham and Women's \\ Hospital, Harvard Medical School, Boston, Massachusetts 02115
}

\begin{abstract}
22 of 61 systemic lupus erythematosus (SLE) patients produced antibodies to the 24 gag protein of HIV-1 demonstrated by Western blotting. 20 of these 22 patients $(91 \%)$ also express the 4B4 idiotype (Id 4B4) previously identified on a human anti-Sm monoclonal antibody called $4 \mathrm{~B} 4$. This represents an enrichment for this Id (seen in only 52\% of SLE patients generally). Eight of these 22 SLE patients also have anti-Sm antibody activity. Sm partially inhibits the antibody binding of p24 gag suggesting immunologic cross-reactivity between the retroviral antigen 24 gag and the autoantigen $\mathrm{Sm}$. Anti-Id 4B4 also inhibits p24 gag antibody binding by as much as $40 \%$. Finally the monoclonal antibody $4 B 4$ showed cross-reactivity to Sm and p24 gag.

The following points emerge from our studies: (a) SLE patients make antibodies to p24 gag of HIV-1, (b) there is a relationship between immunity to p24 gag and a conserved idiotype, and (c) anti-Sm antibodies can cross-react with p24 gag. (J. Clin. Invest. 1990. 85:1866-1871.) autoantibodies • gag proteins $\bullet$ rheumatic diseases
\end{abstract}

\section{Introduction}

Systemic lupus erythematosus (SLE) and Sjögren's syndrome $(\mathrm{SS})^{1}$ are closely related autoimmune rheumatic diseases of unknown etiology. Although genetic and viral factors are considered to be most important (1), sex hormones and stress may also play a role (2).

During the course of screening patients with SLE and primary SS for reactivity to human immunodeficiency virus (HIV-1) proteins (3), we observed an association between antibodies to the p24 gag protein and the presence of an idiotype (Id 4B4) first defined on a human monoclonal antibody capable of binding the small ribonucleoprotein (snRNP) called Sm

This paper was presented at the Tumor Virus Meeting in Cold Spring Harbor, NY, 24-28 May 1989, p. 252.

Address reprint requests to Dr. Howard Dang, Department of Medicine, University of Texas Health Science Center, 7703 Floyd Curl Drive, San Antonio, TX 78284-7874.

Received for publication 14 June 1989 and in revised form 19 December 1989.

1. Abbreviations used in this paper: $\mathrm{KLH}$, keyhole limpet hemocyanin; SS, Sjögren's syndrome.

J. Clin. Invest.

(c) The American Society for Clinical Investigation, Inc.

0021-9738/90/06/1866/06 $\$ 2.00$

Volume 85, June 1990, 1866-1871
(4). $\mathrm{Sm}$ is a snRNP involved in the generation of messenger RNA (5). We previously showed that Id 4B4 was present in SLE patients whether or not they bound Sm, was also present in $28 \%$ of healthy first-degree relatives of SLE patients (6), and Was evolutionarily conserved (4).

We have recently found (3) that 14 of 47 primary SS patients (30\%) are reacting immunologically to the retroviral gag protein p24 (three to p17, none to HTLV-I). Four of these 14 SS patients were also diagnosed as having SLE. Importantly, these four were the only patients among the 14 who expressed Id 4B4. Two of these four SS/SLE overlap patients also bound $\mathrm{Sm}$, an activity present in $30 \%$ of SLE patients and absent in primary SS.

We have now found an additional 18 SLE patients (for a total of 22 patients) who are moderately to strongly positive for antibodies to p24 gag. Twenty of these 22 patients (91\%) express Id 4B4, as compared to the 52\% incidence of Id 4B4 in SLE patients not selected for p24 gag binding. An anti-idiotypic serum inhibits binding of p24 gag. Eight of these 22 patients also bind Sm. Competitive inhibition studies demonstrate that Sm partially inhibits antibody binding of p24 gag, demonstrating immunologic cross-reactivity between the retroviral gag protein $\mathrm{p} 24$ and the snRNP Sm.

\section{Methods}

Serum samples. Sera were obtained from SLE patients examined in the clinics of the University of Texas Health Science Center at San Antonio, Texas, and Brigham and Women's Hospital, Boston, Massachusetts. They fulfilled the American College of Rheumatology (formerly the American Rheumatism Association) criteria for the diagnosis of SLE (7). Additional SLE sera were kindly provided by Drs. M. Reichlin (University of Oklahoma Health Science Center, Oklahoma City, OK), and G. C. Sharp (University of Missouri, Columbia, MO). None of the SLE patients studied were at high risk for acquired immunodeficiency syndrome (AIDS).

Sera seropositive for HIV-1 including p24 gag were obtained from the AIDS Treatment and Evaluation Unit at Tulane University (New Orleans, LA).

Western blot assays. An enzyme-linked immunoelectrotransfer blot (Western blot) technique was used to identify antibodies to HIVrelated antigens. HIV-1 (strain HTLV-III) was propagated in cultures of the $\mathrm{H} 9$ subline of HUT 78 cells. It was partially purified, inactivated with psoralen and ultraviolet light, and then detergent disrupted. Individual HIV proteins were resolved by SDS-PAGE before transfer to a nitrocellulose membrane. Strips of the nitrocellulose membrane (Biotech Research Laboratories, Rockville, MD) were subsequently incubated with normal or SLE sera. Immunoglobulins specifically bound to HIV proteins were visualized by a series of reactions using biotinylated goat anti-human IgG, avidin-conjugated horseradish peroxidase, and the enzyme substrate (4-chloro-1-naphthol).

The Western blot was considered positive for HIV-1 if bands were present at p24, p31, and either gp41 or gp160. No SLE sera reacted 
with gp41 or gp160. The reactions observed with SLE sera were graded either,$-+1-, 1+, 2+, 3+, 4+$, or $5+$ based on the intensity of reaction with p24 gag protein. Only 1 in 100 normal sera gave a $2+$ response, and no normal sera were greater than $2+$ for p24 gag.

A recombinant p24 gag protein was produced in the insect cellbaculovirus expression system (MicroGeneSys, Inc., West Haven, CT). This recombinant p24 is derived from an HIV-1 gag gene fragment that includes all of p24 plus 12 amino acids of the $\mathrm{COOH}$ terminus of p17 and 57 amino acids of the $\mathrm{NH}_{2}$ terminus of p15.

Western blot assays were also used to study reactivity of serum antibodies to proteins of HTLV-I. HTLV-I (strain B2) propagated in HUT 102 were partially purified and inactivated by the same procedures used for HIV-1.

As a control for reactions to cellular proteins present in virus preparations, Western blot assays were performed using nitrocellulose strips containing electrophoretically separated and transferred proteins from a "mock" virus preparation obtained by subjecting supernatants from uninfected $\mathrm{H} 9$ cells to the same purification and inactivation procedure used for virus preparation. Western blot assays were also performed using nitrocellulose strips containing electrophoretically separated and transferred proteins from whole cell lysates of uninfected $\mathrm{H} 9$ cells.

Monoclonal antibody. The human monoclonal anti-Sm antibody designated 4B4 was derived by hybridoma technology. The monoclonal antibody was isolated from culture supernatant by affinity chromatography. Details of this antibody have been described elsewhere (4). Antibody isolated from a Burkitt's lymphoma cell line, ST486 (American Type Culture Collection, Rockville, MD; ATCC CRL 1647) was used as a control.

ELISA. Recombinant p24 gag $(10 \mathrm{ng} / \mathrm{ml})$ or bovine Sm $(10 \mu \mathrm{g} / \mathrm{ml})$ was coated onto microtiter wells (Immunolon II; Dynatech, Alexandria, VA). Nonspecific sites were blocked with PBS containing 1\% BSA (PBS/BSA). Sera (1:250) were added to the antigen-coated wells for 16 $\mathrm{h}$ at $4^{\circ} \mathrm{C}$. Antibody binding was detected by subsequent addition of alkaline phosphatase-conjugated goat anti-human Ig (Sigma Chemical Co., St. Louis, MD; 1:350 final dilution) for $2 \mathrm{~h}$ at room temperature followed by the enzyme substrate $p$-nitrophenyl phosphate (1 $\mathrm{mg} / \mathrm{ml}$ ) in $0.01 \mathrm{M}$ glycine buffer ( $\mathrm{pH} 10.4$ ) containing $1 \mathrm{mM} \mathrm{ZnCl}_{2}, 1$ $\mathrm{mM} \mathrm{MgCl}$. After $1 \mathrm{~h}$, substrate hydrolysis was measured by light absorption at $405 \mathrm{~nm}$. In some experiments $\mu$ and $\gamma$ chain specific immunoconjugates were used.

Inhibition of the antibody binding to recombinant p24 gag or Sm was performed with varying concentrations of Sm, recombinant p24 gag or control antigens, or with a rabbit anti-Id 4B4 previously described (4). The control antigens were denatured DNA (dDNA), keyhole limpet hemocyanin (KLH), ovalbumin (OVA), and normal rabbit IgG (RIgG). The inhibitors were preincubated with the SLE serum for $24 \mathrm{~h}$ at $4^{\circ} \mathrm{C}$ before exposure to wells coated with p24 gag or Sm.

\section{Results}

Identification of antibodies to retroviral proteins by immunoblotting. In the Western blot assay, sera from HIV-1-infected subjects may contain antibodies reactive to HIV proteins designated p17, p31, p51, p55, p66, gp120, gp160 (the apparent relative molecular mass of the proteins of glycoproteins in kilodaltons) (Fig. 1, lane $a$ ). Under the stringent conditions of this assay, reactivity against any protein present on the blots occurs in $<1$ out of 100 normal sera. In contrast to results with sera from normal control subjects, 22 of 61 sera $(36 \%)$ from SLE patients (Fig. 1, lanes $b-j$ ) had $2+$ or greater reactivity against a protein with a relative molecular mass identical to p24 gag, the major core protein of HIV-1. Three sera also reacted against a protein with a relative molecular mass indistinguishable from p17, another HIV-1 gag protein. There was no reactivity to HTLV-I proteins. By ELISA, both serum IgG

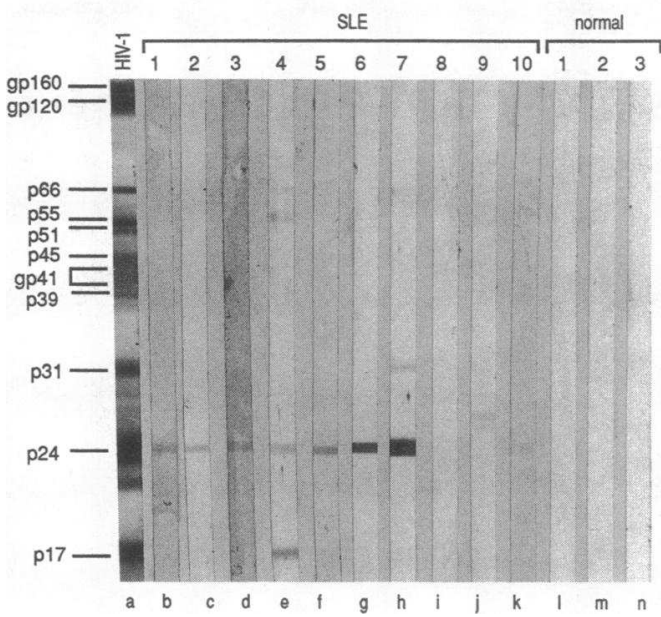

Figure 1. Immunoblot analysis of SLE and control sera reacting with HIV-1 proteins. HIV-1 proteins (strain HTLV-III $I_{B}$, propagated in $\mathrm{H} 9$ cells) were resolved by SDS-PAGE and then transferred to a nitrocellulose membrane. Strips of the nitrocellulose membrane were exposed to sera from an HIV-1-infected individual, SLE patients, or normal subjects. Specifically bound IgG was visualized by standard enzyme-linked immunoblot techniques. (Lane $a$ ) Serum from a patient infected with HIV-1; (lanes $b-k$ ) representative sera from SLE patients (bands with relative molecular mass slightly above p24 represent $\mathrm{B} / \mathrm{B}^{\prime}$ of Sm); and (lanes $l-n$ ) sera from normal donors. Patients 8,9 , and 10 (lanes $i-k$ ) were seronegative for antibodies to p24 gag.

and IgM reacted to p24 gag. There was no correlation between antibodies to p24 gag and hypergammaglobulinemia.

Antibodies to p24 gag are associated with elevated Id 4B4 expression. Id 4B4 is an evolutionarily conserved Id associated with Sm binding $(4,6)$. Of the 61 SLE sera studied in this report, $31(52 \%)$ expressed high levels of Id 4B4 (consistent with our previous reports). 22 of these 61 SLE sera reacted with p24 gag, including the patient (M.C.) whose cells were used to produce the MAb 4B4 (Table I). Importantly, 20 of these $22(91 \%)$ were positive for Id (4B4), a statistically signifcant enrichment of Id 4B4 expression in SLE patients responding immunologically to the retroviral gag protein $(P$ $<0.001$, Yates chi square analysis). Eight of these 22 sera (36\%) were also positive for Sm binding. Seven of these eight patients expressed Id 4B4. Thus, Id 4B4 is more strongly associated with antibodies to p24 gag than with antibodies to Sm.

To further investigate the relationship between p24 gag and Sm, we studied whether Sm could inhibit the binding of p24 gag (Table II). The ability of sera from three SLE patients (N.C., G.A., and G.W.) to bind p24 gag was significantly inhibited 22 to $31 \%(P<0.01)$ by earlier exposure to Sm (Table II and Fig. 2). Sm was unable to inhibit binding of p24 gag in two other patients (S.P. and B.P.) whose serum contained both antibody activities. Three sera with only p24 gag but not Sm binding activity were also unaffected by $\mathrm{Sm}$. Inhibition was specific for Sm since dDNA, KLH, and rabbit Ig were without effect. The only exception was with serum from patient G.A. in which rabbit IgG did inhibit. The reciprocal experiments were performed (Table III). Recombinant p24 gag was able to 
Table I. Systemic Lupus Erythematosus Patients Positive for Antibodies to Retroviral gag Protein p24

\begin{tabular}{|c|c|c|c|}
\hline Patient & p24 & Id 4B4 & Sm antibody \\
\hline T.T. & ++ & + & - \\
\hline J.K. & $+t$ & + & + \\
\hline A.C. & ++ & + & + \\
\hline I.T. & ++ & + & - \\
\hline C.C. & ++ & + & - \\
\hline F.C. & ++ & + & - \\
\hline B.P. & ++ & + & + \\
\hline M.Y. & ++ & + & - \\
\hline G.A. & $+t$ & + & + \\
\hline S.P. & $+t$ & - & + \\
\hline R.M. & ++ & - & - \\
\hline M.S. & $+t$ & + & - \\
\hline G.T. & ++ & + & - \\
\hline M.Z. & ++ & + & - \\
\hline J.E. & ++ & + & - \\
\hline C.O. & ++ & + & - \\
\hline I.V. & +++ & + & - \\
\hline F.G. & $+t+$ & + & - \\
\hline G.W. & ++++ & + & + \\
\hline M.C. & $++t+t$ & + & + \\
\hline N.C. & $+++t+$ & + & + \\
\hline S.C. & +++++ & + & - \\
\hline
\end{tabular}

significantly inhibit Sm binding from 18 from $45 \%(P<0.05)$ in the same three patients (N.C., G.A., and G.W.).

Our results demonstrate partial cross-reactivity between p24 gag and Sm in some SLE sera. 14 sera from individuals infected with HIV-1 had no anti-Sm antibody activity. This is

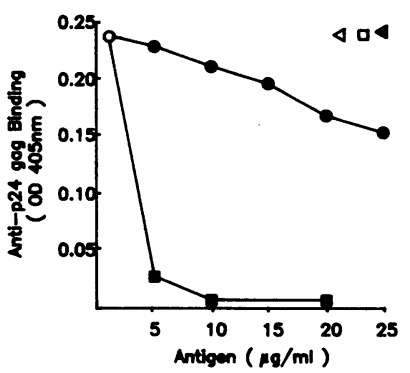

Figure 2. Inhibition of binding of p24 gag of HIV-1 by p24 gag and $\mathrm{Sm}$. The binding of p24 gag by antibodies in the serum of SLE patient N.C. was measured by ELISA with wells coated with recombinant p24 gag. Earlier exposure to p24 gag and to a lesser extent Sm resulted in significant inhibition whereas denatured DNA, KLH, and rabbit immunoglobulin were unable to com-

petitively inhibit p24 gag binding. $০$, none; $\mathrm{n}, \mathrm{p} 24 \mathrm{gag} ; \bullet, \mathrm{Sm} ; \square$, KLH; «, dDNA; ४, Rig.

not surprising since we don't believe that SLE patients are infected with HIV-1 and would not expect HIV-1 infected subjects to make anti-Sm antibodies.

We also studied the ability of anti-idiotype serum to 4B4 to inhibit antibody activity to p24 gag (Table IV). Five of the SLE sera positive for Id 4B4 showed significant inhibition of anti-p24 gag antibody activity (18-41\%) by anti-Id 4B4. Anti-p24 gag antibody in SLE sera that were negative for Id 4B4 were not inhibited by the anti-Id reagent. These results provide further evidence that the Id 4B4 site is related directly or indirectly to the p24 gag binding site. We conclude that the ability of Ig to bind p24 gag is related to Id 4B4 expression.

Anti-Sm human monoclonal antibody 4B4 cross-reacts with p24 gag. Since elevated levels of Id 4B4 are associated with binding of p24 gag, we suspected that the monoclonal antibody 4B4 itself might have this activity. Indeed, a direct binding ELISA demonstrated that 4B4 has antibody activity for both p24 gag and Sm (Fig. 3). Antigenic specificity and cross-reactivity was confirmed by competitive inhibition (Table V).

Table II. Inhibition of Binding of p24 gag by Exposure of SLE Serum to Sm*

\begin{tabular}{|c|c|c|c|c|c|}
\hline \multirow[b]{2}{*}{ Patient } & \multicolumn{5}{|c|}{ Inhibition achieved with } \\
\hline & Nothing & Sm & dDNA & KLH & $R \operatorname{Ig} G$ \\
\hline N.C. & $0.210 \pm 0.007$ & $\begin{array}{c}0.145 \pm 0.005^{\ddagger} \\
(31 \%)\end{array}$ & $\begin{array}{c}0.202 \pm 0.008 \\
(4 \%)\end{array}$ & $\begin{array}{c}0.215 \pm 0.004 \\
(0 \%)\end{array}$ & $\begin{array}{c}0.200 \pm 0.015 \\
(5 \%)\end{array}$ \\
\hline G.A. & $0.150 \pm 0.010$ & $\begin{array}{c}0.110 \pm 0.008^{\ddagger} \\
(27 \%)\end{array}$ & $\begin{array}{c}0.145 \pm 0.009 \\
(3 \%)\end{array}$ & $\begin{array}{c}0.140 \pm 0.010 \\
(7 \%)\end{array}$ & $\begin{array}{c}0.120 \pm 0.020 \\
(20 \%)\end{array}$ \\
\hline G.W. & $0.175 \pm 0.013$ & $\begin{array}{c}0.134 \pm 0.008^{\ddagger} \\
(23 \%)\end{array}$ & $\begin{array}{c}0.180 \pm 0.009 \\
(0 \%)\end{array}$ & $\begin{array}{c}0.181 \pm 0.011 \\
(0 \%)\end{array}$ & $\begin{array}{c}0.170 \pm 0.010 \\
(3 \%)\end{array}$ \\
\hline S.P. & $0.160 \pm 0.010$ & $\begin{array}{c}0.150 \pm 0.006 \\
(4 \%)\end{array}$ & $\begin{array}{c}0.155 \pm 0.006 \\
(3 \%)\end{array}$ & $\begin{array}{c}0.155 \pm 0.009 \\
(3 \%)\end{array}$ & $\begin{array}{c}0.175 \pm 0.011 \\
(0 \%)\end{array}$ \\
\hline B.P. & $0.120 \pm 0.011$ & $\begin{array}{c}0.125 \pm 0.003 \\
(0 \%)\end{array}$ & $\begin{array}{c}0.130 \pm 0.003 \\
(0 \%)\end{array}$ & $\begin{array}{c}0.120 \pm 0.005 \\
(0 \%)\end{array}$ & $\begin{array}{c}0.126 \pm 0.012 \\
(0 \%)\end{array}$ \\
\hline F.G." & $0.225 \pm 0.012$ & $\begin{array}{c}0.220 \pm 0.011 \\
(2 \%)\end{array}$ & $\begin{array}{c}0.215 \pm 0.009 \\
(5 \%)\end{array}$ & $\begin{array}{c}0.220 \pm 0.003 \\
(2 \%)\end{array}$ & $\begin{array}{c}0.210 \pm 0.005 \\
(7 \%)\end{array}$ \\
\hline I.V." & $0.210 \pm 0.017$ & $\begin{array}{c}0.215 \pm 0.009 \\
(0 \%)\end{array}$ & $\begin{array}{c}0.200 \pm 0.012 \\
(5 \%)\end{array}$ & $\begin{array}{c}0.210 \pm 0.011 \\
(0 \%)\end{array}$ & $\begin{array}{c}0.207 \pm 0.014 \\
(2 \%)\end{array}$ \\
\hline C.O." & $0.170 \pm 0.010$ & $\begin{array}{c}0.175 \pm 0.003 \\
(0 \%)\end{array}$ & $\begin{array}{c}0.160 \pm 0.008 \\
(6 \%)\end{array}$ & $\begin{array}{c}0.165 \pm 0.010 \\
(3 \%)\end{array}$ & $\begin{array}{c}0.160 \pm 0.010 \\
(6 \%)\end{array}$ \\
\hline
\end{tabular}

\footnotetext{
* Data expressed as mean OD at $405 \mathrm{~nm} \pm \mathrm{SD}$ in an ELISA measuring anti-p24 gag antibody. Numbers in parentheses are percent inhibition of binding to p24 gag. Antibody activity from normal sera $(n=7)$ was $0.036 \pm 0.012$. Final antigen concentration used for inhibition was $20 \mu \mathrm{g} / \mathrm{ml}$. ‡ Significant difference $(P<0.01, t$ test $)$ compared to wells with no inhibition. ${ }^{8}$ Possibly due to rheumatoid factor activity of anti-Sm antibodies (8). "Seronegative for anti-Sm antibodies.
} 
Table III. Inhibition of Binding of Sm by Exposure of SLE Serum to p24 gag*

\begin{tabular}{|c|c|c|c|c|c|}
\hline \multirow[b]{2}{*}{ Patient } & \multicolumn{5}{|c|}{ Inhibition achieved with } \\
\hline & Nothing & Sm & p24 gag & R Ig & dDNA \\
\hline N.C. & $0.175 \pm 0.012$ & $\begin{array}{c}0.092 \pm 0.003^{\ddagger} \\
(48 \%)\end{array}$ & $\begin{array}{c}0.120 \pm 0.015^{\ddagger} \\
(32 \%)\end{array}$ & $\begin{array}{c}0.180 \pm 0.010 \\
(0 \%)\end{array}$ & $\begin{array}{c}0.170 \pm 0.011 \\
(3 \%)\end{array}$ \\
\hline G.A. & $0.156 \pm 0.006$ & $\begin{array}{c}0.065 \pm 0.010^{\ddagger} \\
(59 \%)\end{array}$ & $\begin{array}{c}0.102 \pm 0.016^{\ddagger} \\
(45 \%)\end{array}$ & $\begin{array}{c}0.138 \pm 0.020 \\
(12 \%)\end{array}$ & $\begin{array}{c}0.152 \pm 0.007 \\
(3 \%)\end{array}$ \\
\hline G.W. & $0.187 \pm 0.020$ & $\begin{array}{c}0.117 \pm 0.015^{\ddagger} \\
(48 \%)\end{array}$ & $\begin{array}{c}0.155 \pm 0.014^{\ddagger} \\
(18 \%)\end{array}$ & $\begin{array}{c}0.182 \pm 0.017 \\
(3 \%)\end{array}$ & $\begin{array}{c}0.196 \pm 0.030 \\
(0 \%)\end{array}$ \\
\hline S.P. & $0.256 \pm 0.023$ & $\begin{array}{c}0.111 \pm 0.007^{\ddagger} \\
(57 \%)\end{array}$ & $\begin{array}{c}0.251 \pm 0.017 \\
(2 \%)\end{array}$ & $\begin{array}{c}0.249 \pm 0.018 \\
(2 \%)\end{array}$ & $\begin{array}{c}0.245 \pm 0.021 \\
(4 \%)\end{array}$ \\
\hline A.C. & $0.211 \pm 0.026$ & $\begin{array}{c}0.134 \pm 0.008^{\ddagger} \\
(37 \%)\end{array}$ & $\begin{array}{c}0.192 \pm 0.010 \\
(10 \%)\end{array}$ & $\begin{array}{c}0.207 \pm 0.009 \\
(2 \%)\end{array}$ & $\begin{array}{c}0.212 \pm 0.017 \\
(0 \%)\end{array}$ \\
\hline M.S." & $0.169 \pm 0.012$ & $\begin{array}{c}0.107 \pm 0.015^{\ddagger} \\
(37 \%)\end{array}$ & $\begin{array}{c}0.170 \pm 0.013 \\
(0 \%)\end{array}$ & $\begin{array}{c}0.162 \pm 0.007 \\
(4 \%)\end{array}$ & $\begin{array}{c}0.159 \pm 0.008 \\
(6 \%)\end{array}$ \\
\hline V.M." & $0.199 \pm 0.021$ & $\begin{array}{c}0.100 \pm 0.006^{\ddagger} \\
(50 \%)\end{array}$ & $\begin{array}{c}0.197 \pm 0.009 \\
(1 \%)\end{array}$ & $\begin{array}{c}0.201 \pm 0.011 \\
(0 \%)\end{array}$ & $\begin{array}{c}0.202 \pm 0.020 \\
(0 \%)\end{array}$ \\
\hline
\end{tabular}

* Data expressed as mean OD at $405 \mathrm{~nm} \pm \mathrm{SD}$ in an ELISA measuring anti-Sm antibody activity. Numbers in parentheses are percent inhibition binding to $\mathrm{Sm}$. Antibody activity from normal sera $(n=7)$ was $0.057 \pm 0.016$. Final antigen concentration used for inhibition was $20 \mu \mathrm{g} / \mathrm{ml}$. ‡ Significant difference $\left(P<0.05, t\right.$ test) compared to wells with no inhibition. ${ }^{8}$ Possibly due to rheumatoid factor activity of anti-Sm antibodies (8). "Seronegative for anti-p24 gag antibodies.

Table IV. Inhibition of Binding of p24 gag by Anti-idiotypic Serum*

\begin{tabular}{lccc}
\hline & \multicolumn{3}{c}{ Inhibition achieved with } \\
\cline { 2 - 4 } Patient & Nothing & Anti-Id 4B4 & Normal R Ig \\
\hline C.O. & $0.183 \pm 0.011$ & $0.109 \pm 0.009^{\ddagger}$ & $0.181 \pm 0.010$ \\
N.C. & $0.244 \pm 0.021$ & $0.179 \pm 0.012^{\ddagger}$ & $(1 \%)$ \\
& & $(27 \%)$ & $0.230 \pm 0.019$ \\
G.A. & $0.200 \pm 0.015$ & $0.147 \pm 0.010^{\ddagger}$ & $(6 \%)$ \\
& & $(27 \%)$ & $0.203 \pm 0.011$ \\
S.C. & $0.203 \pm 0.009$ & $0.153 \pm 0.006^{\ddagger}$ & $(0 \%)$ \\
& & $(25 \%)$ & $0.191 \pm 0.007$ \\
B.P. & $0.155 \pm 0.008$ & $0.130 \pm 0.010^{\ddagger}$ & $(6 \%)$ \\
& & $(18 \%)$ & $0.150 \pm 0.007$ \\
I.V. & $0.255 \pm 0.013$ & $0.230 \pm 0.012^{\ddagger}$ & $0.249 \pm 0.009$ \\
& & $(10 \%)$ & $(3 \%)$ \\
J.E. & $0.152 \pm 0.012$ & $0.149 \pm 0.009$ & $0.147 \pm 0.010$ \\
& & $(2 \%)$ & $(3 \%)$ \\
G.W. & $0.251 \pm 0.016$ & $0.255 \pm 0.019$ & $0.245 \pm 0.013$ \\
& & $(\%)$ & $(3 \%)$ \\
F.G. & $0.221 \pm 0.020$ & $0.225 \pm 0.014$ & $0.230 \pm 0.008$ \\
G.T. & $0.162 \pm 0.009$ & $0.165 \pm 0.009$ & $(0 \%)$ \\
R.M. & & $(0 \%)$ & $155 \pm 0.009$ \\
S.P. & $0.158 \pm 0.0$ & $0.163 \pm 0.009$ & $(4 \%)$ \\
& & $(0 \%)$ & $0.153 \pm 0.009$ \\
& $0.133 \pm 0.010$ & $0.141 \pm 0.010$ & $(3 \%)$ \\
& & $(0 \%)$ & $0.136 \pm 0.007$ \\
& & & $(0 \%)$ \\
\hline
\end{tabular}

* Data presented as mean OD at $405 \mathrm{~nm} \pm \mathrm{SD}$ in an ELISA measuring anti-p24 gag antibody activity. Numbers in parentheses are percent inhibition of binding to p24 gag.

₹ Significant difference $(P<0.05, t$ test $)$ compared to wells with normal RIg.

${ }^{8}$ Seronegative for Id 4B4.

\section{Discussion}

The observation that 22 of 61 patients with SLE (37\%) antibodies to the p24 gag protein of HIV-1 extends our previous observation with SS patients. Previously we found 14 of 47 primary SS patients (30\%) gave moderate to strong reactivity in Western blot against p24 gag (3). Three of our SLE patients also react with p17 gag as did three of the SS patients. None of the SLE or SS patients react with envelope proteins of HIV-1. Similarly Rucheton et al. (9) reported the presence of antibodies in patients with lupus that bind to the gag protein of murine sarcoma virus. Since these patients lack antibodies to HIV-1 envelope proteins, have no clinical evidence for HIV-1 infection, but do have classical autoimmune rheumatic illness, we

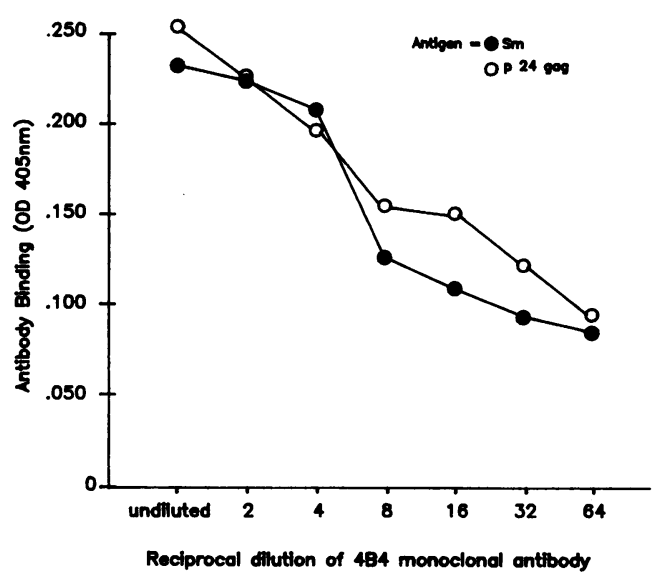

Figure 3. Direct binding of 4B4 to Sm and p24 gag. Dilutions of 4B4 were added to wells coated with p24 gag or Sm. The initial concentration of 4B4 was $130 \mu \mathrm{g} / \mathrm{ml}$. A control monoclonal antibody from the B cell line ST 486 gave OD values of $<0.02$ at equivalent concentrations. 
Table V. Antigen Inhibition of $4 B 4$ Binding to p24 gag or Sm Antigen*

\begin{tabular}{lllll}
\hline & \multicolumn{4}{c}{ Inhibition achieved with } \\
\cline { 2 - 5 } Binding to & Nothing & p24 gag & Sm & OVA \\
\hline p24 gag & \multirow{2}{*}{0.260} & 0.189 & 0.149 & 0.255 \\
& & $(27 \%)$ & $(43 \%)$ & $(2 \%)$ \\
Sm & 0.255 & 0.215 & 0.135 & 0.248 \\
& & $(16 \%)$ & $(47 \%)$ & $(2 \%)$
\end{tabular}

* Data expressed as mean OD at $405 \mathrm{~nm}$ in an ELISA measuring anti-p24 gag or anti-Sm antibody binding. Numbers in parentheses are percent inhibition of $4 \mathrm{~B} 4$ binding to antigen-coated wells. The concentration of $4 \mathrm{~B} 4$ was $8.1 \mu \mathrm{g} / \mathrm{ml}$, and the concentration of inhibitor was $20 \mathrm{ng} / \mathrm{ml}$.

suspect that they may be reacting immunologically to a retrovirus different from HIV-1.

A second major finding in this report is the relationship between antibodies to p24 gag of HIV-1 and Id 4B4 previously related to Sm binding (6). 20 of the 22 SLE patients (91\%) with antibodies to p24 gag express Id 4B4, a conserved interspecies Id whose antigenic determinants are shared between mouse and man (4). Conserved idiotypes are thought to be important in immunoregulation and immune repertoire development.

Eight of the 22 SLE patients (35\%) with antibodies to p24 gag also had "autoantibodies" to $\mathrm{Sm}$, a snRNP involved in the formation of messenger RNA (5). Sm was able to inhibit the binding of p24 gag, and p24 gag inhibited Sm binding in $60 \%$ of cases studied. The monoclonal antibody 4B4 itself which defined this idiotype also binds both $\mathrm{Sm}$ and p24 gag and could be reciprocally inhibited by these antigens. Since both Sm and p24 gag probably contain several non-cross-reactive epitopes, the extent of cross inhibition was limited (18-45\%). No doubt only a limited number of epitopes are shared between these two molecules, a point we are currently investigating. We suggest that in some patients shared epitopes may give rise to antibodies to $\mathrm{Sm}$ through a mechanism involving molecular mimicry (10). "Autoantibodies" would then be a misnomer since the immunogen may be the viral protein and not an autoantigen. In support of this hypothesis is the deduced amino acid sequence of the $B / B^{\prime}$ subunit of $\mathrm{Sm}$ and HIV-1 gag polypeptide. Both molecules contain several regions rich in proline residues $(11,12,13)$, a potential site for cross-reactivity.

It is well known that antibodies to viral proteins may cross-react with self antigens (14). Query and Keene demonstrated that another snRNP of molecular weight 70,000 contains 23 residues homologous to the gag protein p30 from murine leukemia virus (15). The homology was defined by a core consensus sequence that occurs as a tandem repeat in p30 gag of most mammalian $\mathrm{C}$ type retroviruses. Antibodies made against a peptide corresponding to this consensus sequence showed cross-reactivity between the snRNP and viral gag protein. The authors suggest that autoantibodies against $U_{1}$ snRNPs arise by immunization against the retroviral gag protein.

Similarly, Golding et al. (16) reported a highly conserved homologous region shared between the gp41 env protein of
HIV -1 and the amino terminal portion of the $\beta$ chain of all human HLA class II antigens. They found autoantibodies in one-third of individuals infected with HIV-1 which reacted with "native" HLA class II and inhibited T cell proliferation in responses to antigens. They suggested that the molecular mimicry between HIV-1 and HLA class II antigens could lead in AIDS patients to early functional impairment of CD4 T cells by the action of such cross-reactive antibodies.

Our findings relating p24 gag of HIV-1 and the snRNP Sm antigenically raise the possibility of not only sequence homologies but also possible functional homologies. Evidence suggesting a role for a gag protein in mRNA formation was recently reported (17).

\section{Acknowledgments}

We thank Marian Langston for her excellent secretarial assistance, and Hong Luo Zhang and Darrenn Hart for technical assistance and insightful comments.

These studies were supported (in part) by the General Medical Research Service of the Veterans Administration and by grant support from the RGK Foundation, the Jules and Gwen Knapp Charitable Foundation, the Scleroderma Federation, and the National Institutes of Health (AI-22720 and AI-28048 to R. F. Garry).

\section{References}

1. Talal, N. 1976. Disordered immunologic regulation and autoimmunity. Transplant Rev. 31:240-263.

2. Talal, N. 1981. Sex steroid hormones and systemic lupus erythematosus. Arthritis Rheum. 24:1054-1056.

3. Talal, N., M. J. Dauphinée, H. Dang, S. S. Alexander, D. J. Hart, and R. F. Garry. 1990. Detection of serum antibodies to retroviral proteins in primary Sjögren's syndrome (autoimmune exocrinopathy). Arthritis Rheum. In press.

4. Takei, M., H. Dang, R. J. Wang, and N. Talal. 1988. Characteristics of a human monoclonal anti-Sm autoantibody expressing an interspecies idiotype. J. Immunol. 140:3108-3113.

5. Dreyfuss, G., L. Philipson, and I. W. Mattaj. 1988. Ribonucleoprotein particles in cellular processes. J. Cell Biol. 106:1419-1425.

6. Dang, H., M. Takei, D. A. Isenberg, Y. Shoenfeld, R. Blackimer, J. Rauch, and N. Talal. 1988. Expression of an interspecies idiotype in sera of SLE patients and their first degree relatives. Clin. Exp. Immunol. 71:445-451.

7. Tan, E. M., A. S. Cohen, F. Fries, A. T. Masi, D. J. McShane, N. F. Rothfield, J. G. Schaller, N. Talal, and R. J. Winchester. 1982. The 1982 revised criteria for the classification of systemic lupus erythematosus. Arthritis Rheum. 15:1271-1275.

8. Darwin, B. S., J. P. Grudier, C. L. Klatt, and D. S. Pisetsky. 1986. IgG antinuclear antibodies with cross-reactive rheumatoid factor activity. J. Immunol. 137:3796-3801.

9. Rucheon, M., H. Gaafland, H. Fanton, L. Ursale, F. Ferrier, and C. J. Larson. 1985. Presence of circulating antibodies against gag-gene MuLV proteins in patients with autoimmune connective tissue disorders. Virology. 144:468-480.

10. Oldstone, M. B. A. 1987. Molecular mimicry and autoimmune diseases. Cell. 50:819-820.

11. Rokeach, L. A., M. Jannatipour, J. A. Haselby, and S. O. Hoch. 1989. Primary structure of a human small nuclear ribonucleoprotein polypeptide as deduced by cDNA analysis. J. Biol. Chem. 264:50245030.

12. Ohosone, V., J. Mimori, A. Griffith, M. Akizuki, M. Homma, J. Craft, and J. A. Hardin. 1989. Molecular cloning of a cDNA for a B polypeptide of the $\mathrm{U}$ series of small nuclear ribonucleoprotein particles. Proc. Natl. Acad. Sci. USA. 86:4249-4253. 
13. Ratner, L., W. Haseltine, R. Patarca, K. J. Livak, B. Starcich, S. F. Josephs, E. R. Doran, J. A. Rafalski, E. A. Whitehorn, K. Baumeister, L. Ivanoff, S. R. Petteway, Jr., M. L. Pearson, J. A. Lautenberger, T. S. Papas, J. Ghrayeb, N. T. Chang, R. C. Gallo, and F. Wong-Staal. 1985. Complete nucleotide sequence of the AIDS virus, HTLV-III. Nature (Lond.). 313:277-284.

14. Srinivasappa, J., J. Salgusa, B. Prabhakar, M. K. Gentry, M. J. Buchmeier, J. J. Wikton, H. Koprowski, M. B. A. Oldstone, and A. L. Notkins. 1986. Molecular mimicry: frequency of reactivity of monoclonal antiviral antibodies with normal tissue. J. Virol. 57:397-401.

15. Query, C. C., and J. D. Keene. 1987. A human autoimmune protein associated with U1 RNA contains a region of homology that is cross-reactive with retroviral p30 gag antigen. Cell. 51:211-220.

16. Golding, H., G. M. Shearer, K. Hillman, P. Lucas, J. Manischewitz, R. A. Zajuc, M. M. Clerici, R. E. Gress, R. N. Boswell, and B. Golding. Common epitope in human immunodeficiency (HIV)IGP41 and HLA class II elicits immunosuppressive autoantibodies capable of contributing to immune dysfunction in HIV-1-infected individuals. J. Clin. Invest. 83:1430-1435.

17. Nash, M., N. Herzog, and J. Arlinghaus. 1989. Involvement of a truncated gag gene polyprotein in retrovirus mRNA splicing. RNA Tumor Viruses (Cold Spring Harbor Symposium). 89. (Abstr.) 